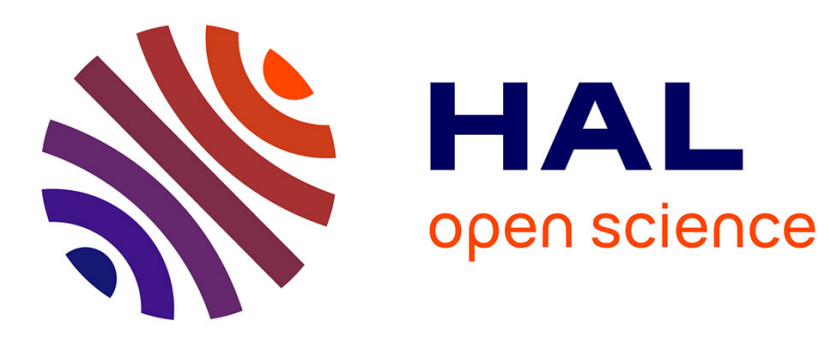

\title{
Doxycycline and sulfadimethoxine transfer from cross-contaminated feed to chicken tissues
}

Giulia Segato, Cristiana Benetti, Roberto Angeletti, Clara Montesissa, Giancarlo Biancotto

\section{- To cite this version:}

Giulia Segato, Cristiana Benetti, Roberto Angeletti, Clara Montesissa, Giancarlo Biancotto. Doxycycline and sulfadimethoxine transfer from cross-contaminated feed to chicken tissues. Food Additives and Contaminants, 2011, 28 (07), pp.860-868. 10.1080/19440049.2011.569574 . hal-00704671

\section{HAL Id: hal-00704671 \\ https://hal.science/hal-00704671}

Submitted on 6 Jun 2012

HAL is a multi-disciplinary open access archive for the deposit and dissemination of scientific research documents, whether they are published or not. The documents may come from teaching and research institutions in France or abroad, or from public or private research centers.
L'archive ouverte pluridisciplinaire HAL, est destinée au dépôt et à la diffusion de documents scientifiques de niveau recherche, publiés ou non, émanant des établissements d'enseignement et de recherche français ou étrangers, des laboratoires publics ou privés. 


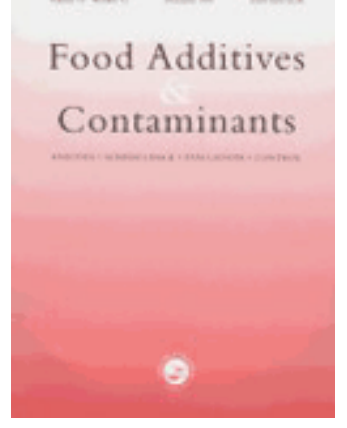

\section{Doxycycline and sulfadimethoxine transfer from cross- contaminated feed to chicken tissues}

\begin{tabular}{|c|c|}
\hline Journal: & Food Additives and Contaminants \\
\hline Manuscript ID: & TFAC-2010-491.R1 \\
\hline Manuscript Type: & Original Research Paper \\
\hline $\begin{array}{l}\text { Date Submitted by the } \\
\text { Author: }\end{array}$ & $17-F e b-2011$ \\
\hline Complete List of Authors: & $\begin{array}{l}\text { Segato, Giulia; Istituto Zooprofilattico Sperimentale delle Venezie, } \\
\text { Chimica } \\
\text { benetti, cristiana; Istituto Zooprofilattico Sperimentale delle } \\
\text { Venezie, Chemistry } \\
\text { angeletti, roberto; Istituto Zooprofilattico Sperimentale delle } \\
\text { Venezie, Chemistry } \\
\text { Montesissa, Clara; Università di Padova, Sanità pubblica, Patol. } \\
\text { Comp. e Igiene Veterinaria } \\
\text { biancotto, giancarlo; Istituto Zooprofilattico Sperimentale delle } \\
\text { Venezie, Chimica }\end{array}$ \\
\hline Methods/Techniques: & $\begin{array}{l}\text { Chromatography - LC/MS, Chromatography - HPLC, Risk } \\
\text { assessment }\end{array}$ \\
\hline Additives/Contaminants: & $\begin{array}{l}\text { Veterinary drug residues - sulphonamides, Veterinary drug residues } \\
\text { - tetracycline }\end{array}$ \\
\hline Food Types: & Animal products - meat, Animal feedingstuffs \\
\hline
\end{tabular}

\section{SCHOLARONE" Manuscripts}


1 Doxycycline and sulfadimethoxine transfer from cross-contaminated

\section{2 feed to chicken tissues}

4 Giulia Segato $^{a}$, Cristiana Benetti ${ }^{a}$, Roberto Angeletti ${ }^{a}$, Clara Montesissa ${ }^{b}$ and

5 Giancarlo Biancotto ${ }^{\mathrm{a}^{*}}$

6

7

$8 \quad$ a Istituto Zooprofilattico Sperimentale delle Venezie

9 Viale dell’Univeristà 10. 35020 Legnaro (Pd) - Italy.

10

11 b Dipartimento Sanità pubblica, Patol. Comp. e Igiene Veterinaria

12 Viale dell'Univeristà 16. 35020 Legnaro (Pd) - Italy.

$14 *$ Corresponding author. Email: gbiancotto@izsvenezie.it 


\section{Abstract}

16 During feed preparation at feed mills or during feed mixing in bins at farms, the 17 accidental contamination of feed at trace levels by veterinary drug residues, commonly 18 known as carry-over, can accidentally but frequently occur. To evaluate the 19 concentrations of residual antimicrobials in poultry edible tissues, due to contaminated 20 feed, sulfadimethoxine and doxycycline were administered for 10 days to chickens in 21 poultry feed incurred at the contamination levels frequently found during national feed 22 monitoring programs (1-5 mg/kg). Sulfadimethoxine and doxycycline residual 23 concentrations detected in muscle ( $<\mathrm{LoD}$ and $31 \mu \mathrm{g} \mathrm{kg}^{-1}$ respectively), liver $\left(13 \mu \mathrm{g} \mathrm{kg}^{-1}\right.$ 24 and $56 \mu \mathrm{g} \mathrm{kg}^{-1}$ respectively) and kidney (56 $\mathrm{g} \mathrm{kg}^{-1}$ and $115 \mu \mathrm{g} \mathrm{kg}^{-1}$ respectively) were 25 compared with their maximum residue limits (MRLs) fixed by EC 470/2009 and EU $2637 / 2010$ Regulations for a preliminary risk evaluation.

28 Keywords: sulfonamides, tetracyclines, cross contamination, animal feedstuff, residues 29 


\section{Introduction}

31 Feed containing veterinary drugs and additives are commonly prepared following Good

32 Manufacturing Practice (GMP) guidelines and employed as medicated feed in livestock

33 to treat animal diseases, to guarantee animal welfare and consequently to increase

34 animal weight increase and producer's economic incomes.

36 In the feed industry, almost all mixed feed formulations are prepared in multi-product

37 plants and cross-contamination cannot be ruled out for carry-over of active ingredients

38 from previous formulations. To prevent cross-contamination several technical steps

39 must be taken by feed operators according to Annex II Reg 183/2005 (European

40 Parliament and Council 2005) further to the separation of medicated feedstuff

41 production lines from the non-medicated (Heberer et al. 2007).

43 However, it is well known that contamination of non-medicated feed by residues of

44 active ingredients like antimicrobials or coccidiostats, may occur at several steps during

45 the whole production process. Further to the critical contamination of production lines,

46 contamination can also occur during storage at feed mills, transport to farms and,

47 eventually, at the farm during storage, manipulation and mixing operations.

49 The accidental administration of feed contaminated with pharmacologically active

50 residues can cause the marketing of food of animal origin containing drug residues, for

51 which the zero level applies, or at concentrations greater than the authorised MRL.

52 In 2009 a guideline on the GMP and the use of medicated feed (FEFAC 2009) was

53 published, and the European Food Safety Authority (EFSA) has published several 
54 opinions on the risk for animal and consumer's health related to the carry-over of

55 coccidiostats or histomonostats into non-target feed contaminated at the $2 \%, 5 \%$ and $10 \%$ of the highest authorised concentrations for target species (EFSA 2007-2008).

For those compounds EFSA generally concluded that adverse effects and consequently the associated risk would be negligible; however the European Commission lowered the maximum levels of coccidiostats and histomonostats in non-target feeds, at $1 \%$ or $3 \%$ of the maximum adopted concentrations by Commission Directive 2009/8/EC (EU Commission 2009).

63 Despite the fact that unavoidable contamination may occur with antimicrobials, no similar approach has yet been adopted for such veterinary drugs. For these compounds the carry-over can occur during medicated feed production as reported by McEvoy (2002) and Kennedy et al. (2000) reviewing the origins of cross-contamination and the consequences on food safety. The results of the feed monitoring conducted in Northern Ireland in 1996 confirmed tetracyclines, sulfonamides, penicillins and ionophores as the most frequently contaminating drugs.

The occurrence of residues in eggs after sulfonamide administration via feed to laying hens was studied by Roudouth and Garnier 2002; Tansakul et al. 2007; the occurrence of coccidiostats in eggs was studied by Mortier et al. 2005; Rosen J. 2001; Yakkundi et al., 2002. The distribution of residues between yolk and white in eggs was studied by Kan and Petz 2000 for veterinary drugs while Mulder et al. 2005 studied the distribution of halofuginone and toltrazuril. Other papers have presented data on the transfer of coccidiostats or anthelmintics at cross-contamination levels from bovine feed to milk 
78 (Kan and Meijer 2007), of chlortetracycline from feed to pig tissue ( Kennedy et al.

79 2000) and of diclazuril from poultry feed to meat (Mortier et al. 2005).

The general picture confirmed that further to feed contamination levels the residual concentrations in food of animal origin strictly depends on the chemical compound, the animal species, and the period of feed administration.

As it is currently accepted that carry-over seems to be hardly avoidable under standard production, storage and manipulation conditions, the cross-contamination of feedstuffs by veterinary drugs is an important issue and still a matter of concern.

88

89 Doxycycline and sulfadimethoxine are currently used for the preparation of medicated

90 feed for swine therapy. For this purpose doxycycline is commercially available in 91 premix at $0.05 \%$ concentration and medicated feed is prepared by diluting $4000-6000 \mathrm{~g}$ 92 premix in $1000 \mathrm{~kg}$ of feed to get a final maximum concentration of doxycycline at 300 $93 \mathrm{mg} \mathrm{kg}^{-1}$ in complete medicated feed.

95 Sulfadimethoxine premixes for oral administration to young swine contain $200 \mathrm{~g}$ of 96 active ingredient in $1000 \mathrm{~g}$ of product. The recommended dose in medicated feed is 97 prepared by diluting $1 \mathrm{~kg}$ premix in $100 \mathrm{~kg}$ feed to get a final maximum concentration 98 equal to $2000 \mathrm{mg} \mathrm{kg}^{-1}$ in complete medicated feed.

99

100 Such high concentrations can give rise to frequent contamination of feed later prepared 101 in the same line, for the same or other animal species. 
102 This study is therefore intended to generate information on the transfer of

103 sulfadimethoxine and doxycycline to chicken tissues, when feed contaminated at the

104 carry-over concentration magnitude-detected during official monitoring plans- is

105 administered to poultry. The conditions adopted were those of a "worse scenario" in

106 terms of length of administration and absence of withdrawal time.

107

108 Eventually the residue concentrations measured were compared with MRLs established

109 by the EU Regulation 470/2009 (EU Parliament and Council 2009) and by EU

110 Regulation 37/2010 (EU Commission 2010) for further consideration.

111

112 Materials and methods

113 Feed and feed contamination

114 Complete feed for fattening chickens was produced by Agricola Tre Valli (Valpanteno,

115 Verona, Italy). Composition: moisture $12.5 \%$, crude protein $19 \%$, fat $8.8 \%$, crude fiber $1163 \%$, crude ash $5 \%$, methionine $0.75 \%$. Integration to $100 \mathrm{~g}$ of product: vitamin A 8.0

117 IU, vitamin D3 $2.0 \mathrm{IU}$, vitamin E $20 \mathrm{mg}, \mathrm{Cu}\left(\mathrm{SO}_{4}\right) 5 \mathrm{H}_{2} \mathrm{O} 10 \mathrm{mg}$, 6-Phyitase 600 FTU.

118 About $15 \mathrm{~kg}$ of feed for fattening chickens (free from any veterinary drug) were spiked

119 with an aqueous solutions of doxycycline to achieve a theoretical concentration of 4

$120 \mathrm{mg} \mathrm{kg}^{-1}$; while other $15 \mathrm{~kg}$ were spiked with an aqueous solution of sulfadimethoxine to

121 produce a final concentration of about $3 \mathrm{mg} \mathrm{kg}^{-1}$. Briefly: an aqueous solution of 122 doxycycline (60 $\mathrm{mg}$ in about $0.5 \mathrm{l}$ ) was sprayed over $15 \mathrm{~kg}$ of feedstuff previously 123 spread over a clean surface. Analogously an aqueous solution of sulfadimethoxine (45 $124 \mathrm{mg}$ in about $0.5 \mathrm{l}$ ) was sprayed over a second lot of $15 \mathrm{~kg}$ of feedstuff previously spread 
125 over a clean surface. Each spiked material was mixed several times during the drying 126 period, and finally homogenised before sampling preparation.

127

128 Both contaminated feedstuffs were dried in a semi-dark room to get a final aqueous 129 content lower than 13\%. From each bulk, single samples (150 g each) destined to each

130 individual animal were prepared in paper bags and stored in the refrigerator until the 131 day of their use; a total of 8 samples per day per treatment were stored for the study.

132 To assess the average concentration of each compound in the corresponding bulk, one

133 further feed sample per day of administration was prepared, stored in the same 134 conditions and analysed by HPLC: 10 samples from each contaminated bulk were 135 therefore available to determine the actual average concentration and variations which 136 might occur during storage.

138 Measured doxycycline and sulfadimethoxine concentration in feed were (mean $\pm \mathrm{SD}$ ):

$139(3.79 \pm 0.28) \mathrm{mg} \mathrm{kg}^{-1}$ and $(2.28 \pm 0.17) \mathrm{mg} \mathrm{kg}^{-1}$, respectively, (see section 3.Results).

141 Animals and treatments

142 The project fulfilled the requirements of Italian Law n. 116/92 and further amendments

143 on the protection and welfare of animals used in experiments. Twenty vaccinated 144 chickens about 20 days old were weighted, allocated in cages ( 2 birds per cage) and fed 145 dedicated feed and water ad libitum, for acclimatisation. After 18 days the animals 146 were weighted and randomly allocated in three groups: group 1 (control), 4 animals; 147 group 2 (doxycycline) 8 animals; group 3 (sulfadimethoxine) 8 animals. 
148 The diet of group 1 remained the same of the acclimatisation period, free of any

149 veterinary drug.

150 The 8 chickens of group 2 were fed the same feed of the acclimatisation period,

151 contaminated with doxycycline (mean concentration $3.79 \pm 0.28 \mathrm{mg} \mathrm{kg}^{-1}$ ).

152

153 The 8 chickens of group 3 were fed the same feed used during the acclimatisation

154 period, contaminated with sulfadimethoxine (mean concentration $2.28 \pm 0.17 \mathrm{mg} \mathrm{kg}^{-1}$ ).

155 Each animal received about $150 \mathrm{~g}$ daily of the feedstuff -contaminated or not - over a

156 period of ten days and was weighted at the beginning and at the end of the "treatment"

157 period.

158

159 On the eleventh day, animals were sacrificed and muscle (breast), liver and kidney were

160 collected and stored at $-20^{\circ} \mathrm{C}$ before analyses.

161

162 Analytical methods

163 Tissues were analysed to detect and quantify doxycycline and sulfadimethoxine by 164 internal methods validated according to the guideline laid down by Decision 165 657/2002/EC (EU Commission 2002).

166 Briefly the methods are hereby summarised.

167 All solvents (methanol $-\mathrm{MeOH}$, acetonitrile $-\mathrm{ACN}$ ) were of HPLC grade and all of the 168 chemicals (succinic acid, oxalic acid, copper sulphate $\left(\mathrm{CuSO}_{4}\right)$, citric acid, disodium 169 hydrogen phosphate dihydrate $\left(\mathrm{Na}_{2} \mathrm{HPO}_{4} \cdot 2 \mathrm{H}_{2} \mathrm{O}\right)$, hydrochloric acid $(\mathrm{HCl}) 1 \mathrm{~N}$, formic 170 acid, acetic acid, ethylenediaminetetracetic acid (EDTA), sodium chloride ( $\mathrm{NaCl})$, 171 aqueous ammonia solution $33 \%$ were all of analytical reagent grade. Distilled water 
172 was de-ionised by an ultrapure water system (Sartorius Stedim Biotec, France).

173 Doxycycline and sulfadimethoxine-d6 (sulfadimethoxine-d6) pure standards were 174 purchased from Fluka (Milan, Italy), sulfadimethoxine and metacycline pure standards

175 were purchased from Riedel de Haen (Milan, Italy). A stock solution of $1000 \mathrm{mg} \mathrm{l}^{-1}$ for 176 each drug was prepared by dissolving the appropriate amount of each substance in 177 methanol. The intermediate working standard solutions for fortification and calibration 178 curves (sulfadimethoxine, sulfadimethoxine-d6, doxycycline and metacycline: $1 \mathrm{mg} \mathrm{1^{-1 }}$ ) 179 were prepared daily by diluting separately the correspondent stock solution with 180 methanol.

182 Chelating sepharose fast flow was purchased from GE Healthcare (Uppsala, Sweden); 183 OASIS HLB ${ }^{\circledR} 60 \mathrm{mg} / 3 \mathrm{ml}$ solid phase extraction (SPE) columns were purchase by 184 Waters (Milford, MA, USA).

186 Agilent SampliQ® QuEChERS EN extraction kit 5982-5650 and Agilent SampliQ®

187 QuEChERS EN fatty dispersive-SPE kit for $15 \mathrm{ml} 5982-5156$ were purchased from 188 Agilent (Agilent Tecnologies Inc., DE, USA).

190 Analysis of doxycycline and metacycline (internal standard) was performed on a liquid 191 chromatographic system (HPLC) Alliance 2695 provided with a quaternary solvent 192 delivery system, a column heater module and a sample cooling device, coupled to a 193 diode array detector (DAD, 2996) from Waters (Milford, MA, USA); the 194 chromatographic column was a Supelco Ascentis Express® C18 column, $2.7 \mu \mathrm{m},(150$ $195 \times$ x 4.6) mm, purchased from Supelco (Milan, Italy). HPLC analysis of sulfadimethoxine 
196 and sulfadimethoxine-d6 was performed by an HPLC Alliance 2695 provided with a

197 quaternary solvent delivery system, a column heater module and a sample cooling

198 device coupled to a QuattroUltima® triple quadrupole system (MSMS) provided with

199 an ESI source by Waters (Milford, MA, USA); the chromatographic column was an

200 XTerra® Phenyl column, $3.5 \mu \mathrm{m},(100 \times 2.1) \mathrm{mm}$, purchased from Waters (Milford, 201 MA, USA).

202

203 Doxycycline in chicken tissues

204 The procedure was based on the method proposed by Cristofani et al., 2009.

$2053 \mathrm{~g}$ of homogenised tissue were extracted with $20 \mathrm{ml}$ of succinic acid $0.1 \mathrm{M} \mathrm{pH} 4$ and 206 with $20 \mathrm{ml}$ of $\mathrm{MeOH}$ by mechanical shaking for $30 \mathrm{sec}$ and by sonication in an 207 ultrasonic bath for $10 \mathrm{~min}$. Liquid phase was separated from solid residue by 208 centrifugation at $5000 \mathrm{~g}$ for $10 \mathrm{~min}$. Extraction was repeated a second time by adding 10 $209 \mathrm{ml}$ of succinic acid $0.1 \mathrm{M} \mathrm{pH} 4$ and $10 \mathrm{ml}$ of $\mathrm{MeOH}$. After centrifugation at $5000 \mathrm{~g}$ for $21010 \mathrm{~min}$, extracts were re-unified and purified through Metal Chelate Affinity

211 Chromatography (MCAC) columns activated with $6 \mathrm{ml}$ of distilled water, $3 \mathrm{ml}$ of $212 \mathrm{CuSO}_{4} 10 \mathrm{mM}$ and $4 \mathrm{ml}$ of distilled water. After extracts loading, columns were washed 213 with $2 \mathrm{ml}$ of succinic acid $0.1 \mathrm{M} \mathrm{pH} \mathrm{4,} 2 \mathrm{ml}$ of distilled water, $2 \mathrm{ml}$ of $\mathrm{MeOH}$ and $2 \mathrm{ml}$ 214 of distilled water; finally elution was performed by application of $8 \mathrm{ml}$ of McIlvaine 215 buffer.

217 The eluate was purified by OASIS HLB® SPE columns $(60 \mathrm{mg}, 3 \mathrm{ml})$ previously 218 activated with $3 \mathrm{ml}$ of $\mathrm{MeOH}, 3 \mathrm{ml}$ of $\mathrm{HCl} 1 \mathrm{~N}, 3 \mathrm{ml}$ of distilled water and washed with $2193 \mathrm{ml}$ of distilled water. Elution was achieved by $5 \mathrm{ml}$ of $\mathrm{MeOH}$. Solvent was evaporated 
to dryness under $\mathrm{N}_{2}$ streaming and the residue was re-dissolved with $0.5 \mathrm{ml}$ of oxalic acid $0.01 \mathrm{M}$ before injection in HPLC-DAD.

222

Doxycycline determination was performed by HPLC-DAD according to the 224 chromatographic and detection conditions reported in table 1.

Insert table 1

Quantification was performed against external calibration in pure solvent, as matrix effects were negligible, and quantified concentrations were corrected for recovery. Metacycline was added as internal standard at the beginning of the procedure in unknown samples, not for strict quantitative purposes, but to prove, by an estimate of its

230 detection, the good application of the method on each single sample.

231 The relevant method characteristics are reported in table 3.

232

\section{Sulfadimethoxine in chicken tissues}

234 To $2 \mathrm{~g}$ of homogenised tissue $8 \mathrm{ml}$ of de-ionised water were added and the mixture was 235 shaken by vortex for $30 \mathrm{sec}$. Acetic acid (1\% in ACN, $10 \mathrm{ml})$ was added and the tubes 236 were manually shacked for $30 \mathrm{sec}$; then an Agilent SampliQ® QuEChERS EN 237 extraction salt packet was added to each tube. Sample tubes were capped tightly and 238 shaken vigorously for $1 \mathrm{~min}$.

240 After centrifugation at $5000 \mathrm{~g}$ for $5 \mathrm{~min}$, an aliquot of the $\mathrm{ACN}$ layer $(6 \mathrm{ml})$ was 241 transferred into an Agilent SampliQ® QuEChERS EN fatty dispersive-SPE $15 \mathrm{ml}$ tube 242 containing $150 \mathrm{mg}$ of PSA, $150 \mathrm{mg}$ of C18EC and $900 \mathrm{mg}$ of anhydrous MgSO4. The 243 samples were vortexed for $2 \mathrm{~min}$ and centrifuged at $5000 \mathrm{~g}$ for $5 \mathrm{~min} .2 \mathrm{ml}$ of each 
244 purified extract were transferred into an empty tube and evaporated to dryness under $\mathrm{N}_{2}$

245 streaming. The residue was re-suspended in $0.8 \mathrm{ml}$ of a solution of formic acid $0.05 \mathrm{M}$

246 and ACN (85/15, v/v) before LC-MS/MS analysis. Sulfadimethoxine determination was

247 performed by LC-MS/MS according to the chromatographic and spectrometric

248 conditions reported in table 2.

249

Insert table 2

250 Quantitative analysis was achieved by internal standard method where deuterated

251 sulfadimethoxine (sulfadimethoxine-d6) was chosen as internal standard introduced in

252 each sample at the beginning of the analytical process. No correction for recovery was

253 applied in this case.

254 Relevant method characteristics are reported in table 3. 


\section{Results}

256 Feed and dosage

257 Feed contamination by both doxycycline and sulfadimethoxine was homogeneous. By 258 analysing 10 independent feed samples, stored for the same time and in the same 259 refrigerating conditions of the feed administered to chickens, no significant differences 260 in concentrations were observed in any tested samples proving the good homogeneity 261 and stability of contaminated feed (Grubbs test, $\mathrm{p}=0.95$ ). Measured mean 262 concentrations were: $(3.79 \pm 0.28) \mathrm{mg} \mathrm{kg}^{-1}$ of doxycycline and $(2.28 \pm 0.17) \mathrm{mg} \mathrm{kg}^{-1}$ of 263 sulfadimethoxine.

265 On the day of their arrival chickens were about 20 days old, with an average weight of $2661.1 \mathrm{~kg}$ (in the range $1.0-1.2 \mathrm{~kg}$ ) and after the acclimatisation period the weights ranged 267 between 2.0 and $2.5 \mathrm{~kg}$. Each chicken in group 2 received about $0.57 \mathrm{mg} \mathrm{day}^{-1}$ of 268 doxycycline, while chickens in group 3 received about $0.34 \mathrm{mg} \mathrm{day}^{-1}$ of 269 sulfadimethoxine. During the treatment period of 10 days, a theoretical daily dose of $270 \quad 0.22 \mathrm{mg} \mathrm{kg}^{-1}$ body weight (b.w.) and of $0.13 \mathrm{mg} \mathrm{kg}^{-1}$ b.w. was estimated for doxycycline 271 and sulfadimethoxine respectively, considering the average weights of birds.

272

\section{Analytical methods}

274 Trueness, precision, decision limit, detection capability, limit of detection (LoD) and 275 limit of quantification (LoQ) were estimated by analyzing 18 replicates of tissue spiked 276 at 4 concentration levels around the MRL on three different days (6 replicates per level 277 per day) under intra-lab reproducibility conditions. LoD and LoQ were extrapolated 278 according to ISO 11843 approach based on the same data set. 
279 The most relevant performance characteristics of both methods are summarised in table $280 \quad 3$

Insert table 3

282 In figure 1 representative HPLC-DAD chromatograms of a standard solution of 283 doxycycline (at a concentration corresponding to $50 \mu \mathrm{g} \mathrm{kg}^{-1}$ on sample), a negative 284 muscle sample, a muscle sample fortified with doxycycline at $50 \mathrm{\mu g} \mathrm{kg}^{1}$ and an incurred 285 muscle sample (doxycycline measured concentration: $48 \mu \mathrm{g} \mathrm{kg}^{-1}$ ).

Insert figure 1

287 In figure 2 representative LC-MS/MS chromatograms of a standard solution of 288 sulfadimethoxine (at a concentration corresponding to $20 \mu \mathrm{g} \mathrm{kg}^{-1}$ on sample), a negative 289 muscle sample, a muscle sample fortified with sulfadimethoxine at $10 \mu \mathrm{g} \mathrm{kg}^{-1}$ and an 290 incurred muscle sample (estimated concentration: $7 \mu \mathrm{g} \mathrm{kg}^{-1}$ ).

Insert figure 2

292

293 Transfer of veterinary drugs in chicken tissues

294 Doxycycline and sulfadimethoxine concentrations measured in muscle, liver and kidney 295 are reported in table 4. In the case of sulfadimethoxine in chicken muscle, the estimated 296 concentrations were lower than the extrapolated LoD: when S/N ratio was still adequate 297 for an approximate quantitative evaluation these figures were considered and reported in 298 italic in table 4.

Insert table 4

300

$301 \quad$ Discussion 
302 The doxycycline contaminant level adopted in this study (about $3.8 \mathrm{mg} \mathrm{kg}^{-1}$ ) and that of

303 sulfadimethoxine (about $2.3 \mathrm{mg} \mathrm{kg}^{-1}$ ) were based on the cross-over concentrations (1-5

$304 \mathrm{mg} \mathrm{kg}^{-1}$ ) frequently detected in not-compliant feed samples, during official routine

305 controls. These levels correspond to about $1.3 \%$ and $0.11 \%$ respectively of the original

306 highest dose used in medicated feed for swine. Both the percentage levels adopted are

307 lower than those chosen by EFSA for the risk assessment of coccidiostats and 308 histomonostats (3-10\%).

309

310 The administration period was chosen on the basis of the worst case scenario:

311 considering that a typical commercial feedlot is produced to satisfy 1 week farming

312 requirements, a period of 10 days should guarantee residue accumulation comparable to

313 a real situation. Furthermore, considering that doxycycline and sulfadimethoxine half-

314 times $\left(\mathrm{t}_{1 / 2}\right)$ in circulating blood are 15-22 hrs and about $16 \mathrm{hrs}$, respectively (EMEA

315 1996; Epstein and Ashworth 1989) the steady state concentrations ( $\left.5 \mathrm{x} \mathrm{t}_{1 / 2}\right)$ might be

316 reached also in tissues within the experimental period of 10 days.

318 During treatments the animals did not show symptoms of sufferance and feed intake

319 was regular. Though feed dose was available in a single pot per cage, and both birds had

320 contemporary access to, the absence of significant different weight gains during the

321 experimental period minimize the possibility that single animals could be exposed to

322 significantly different drug intake.

324 The method adopted for doxycycline analysis in chicken tissues is actually a multi325 residue method further applicable to the detection and quantification of tetracycline, 
326 chlortetracycline, oxytetracycline and their epimers (data not shown). It is based on the 327 well known MCAC purification approach, followed by a further purification step 328 through an Oasis HLB SPE, which guarantees a much cleaner extract. For quantitative 329 analysis the recovery factor estimated through the validation process was applied.

331 The method adopted for sulfadimethoxine in chicken tissues is also a multi-residue 332 method applicable to the detection and quantification of sulfaquinoxaline, 333 sulfachloropiridazine, suladiazine, sulfadoxine, sulfaisoxazole, sulfamerazine, 334 sulfamethazine, sulfamethoxazole, sulfamethoxipiridazine, sulfamonomethoxine, 335 sulfapiridine, sulfathiazole (data not shown) further to sulfadimethoxine. A novel 336 QuEChERS approach, employing two subsequent different dispersive phases, was 337 tested and cleaner purified extracts with higher recoveries were achieved with respect 338 to traditional SCX SPE previously employed. The use of deuterated sulfadimethoxine 339 (sulfadimethoxine-d6), as appropriate internal standard, allowed a quantitative estimate 340 of sulfadimethoxine concentration in all samples without the application of recovery 341 factors. Both methods were validated according to the guidelines established by 342 Decision 657/2002/EC (EU Commission 2002) and were found to be fit-for-purpose.

343 The average residual concentration of doxycycline and sulfadimethoxine were different 344 in all tissues (see table 5). Mean doxycycline concentration was $31 \mu \mathrm{g} / \mathrm{kg}$ in muscle, 56 $345 \mu \mathrm{g} \mathrm{kg}^{-1}$ in liver and $115 \mu \mathrm{g} \mathrm{kg}^{-1}$ in kidney, whereas sulfadimethoxine was found at an 346 average concentration of $5 \mu \mathrm{g} \mathrm{kg}^{-1}$ in muscle, $13 \mu \mathrm{g} \mathrm{kg}^{-1}$ in liver and $56 \mu \mathrm{g} \mathrm{kg}^{-1}$ in 347 kidney. 
349 The different residual concentrations were not only a consequence of the different 350 contamination in administered feed, but likely a result of the different absorption, 351 distribution and metabolic behaviour of the drugs; doxycycline, despite the lower logP 352 than sulfadimethoxine, exhibits a greater persistence in tissues. The low 353 sulfadimethoxine dosages adopted in the experiments could have been eliminated faster 354 than expected; as reported for sulfamethazine and sulfadimethoxine (Tansakul et al. 355 2007; Takahashi 1986) some sulfonamides follow a dose dependent kinetics thus 356 potentially increasing the risk of greater residue concentrations in tissues when present 357 at higher concentration in feed.

359 At the experimental conditions adopted, doxycycline and sulfadimethoxine reached in 360 each tissue average concentrations lower than the correspondent MRL. Only in the case 361 of sulfadimethoxine concentrations close to the MRL were found in kidney.

\section{Conclusions}

364 This work verified the role played by feed, cross-contaminated with doxycycline or 365 sulfadimethoxine, in residue accumulation in chicken tissues. At the feed concentrations 366 chosen for this study and in absence of any withdrawal period, in none of the analysed 367 tissue were violative concentrations of doxycycline or sulfadimethoxine found, 368 notwithstanding the long administration period. In the case of doxycycline the highest 369 concentration found in muscle was lower than $50 \%$ of the MRL, whereas in liver and 370 kidney they were lower than $30 \%$. In the case of sulfadimethoxine, the highest residual 371 concentration in muscle was lower than $10 \%$ of the corresponding MRL, the highest in 
372 liver was lower than $20 \%$, and only in kidney it reached a concentration close to the 373 MRL.

374

375 To ensure good manufacturing practice with pharmacologically active substances and to

376 help official food and feed controls, European levels of tolerance in feed, as acceptable

377 amounts of veterinary drugs in compound feed, could be established based on the

378 respect of residue tolerance in animal products established by the EU Regulations. Thus

379 the analytical results of this study, associated to consumer exposure data, could

380 represent a starting point for a risk assessment evaluation by competent authorities

381 aimed at the definition of safe maximum feed contamination levels.

382

383 Acknowledgements

384 The project was financially supported by Italian Ministry of Health. The authors would

385 like to thank Bruna Allegretta and Valentina Mozzo for their technical assistance 386 throughout the study. 


\section{References}

388 Cristofani, E.; Antonini, C.; Tovo, G.; Fioroni, L.; Piersanti, A.; Galarini, R. 2009. A 389 confirmatory method for the determination of tetracyclines in muscle using high390 performance liquid chromatography with diode-array detection. Anal. Chim. Acta 637: $39140-46$.

392

393 EU Commission. 1996. Commission Decision 657/2002/EC implementing Council 394 Directive 96/23/EC concerning the performance of the analytical methods and the 395 interpretation of the results. Official Journal of the European Communities, L221: 8-36. 396

397 EU Commission. 2009. Commission Directive 2009/8/EC amending Annex I to 398 Directive 2002/32/EC of the European parliament and of the Council as regards 399 maximum levels of unavoidable carry-over of coccidiostats or histomonostats in non400 target feed. Official Journal of the European Union L 40: 19-25.

401

402 EU Parliament and Council. 2005. Commission Regulation (EC) 183/2005 laying down 403 requirements for feed hygiene. Official Journal of the European Union L35: 1-22 404

405 EU Commission. 2010. Commission Regulation (EC) 37/2010 on pharmacologically 406 active substances and their classification regarding maximum residue limits in foodstuff 407 of animal origin. Official Journal of the European Union, L15: 1-72.

408

409 EU Parliament and Council. 2009. Regulation (EC) 470/2009, laying down Community 410 procedures for the establishments of the residue limits of pharmacologically active 
411 substances in foodstuffs of animal origin, repealing Council Regulation (EEC) No

412 2377/90 and amending Directive 2001/82/EC of the European Parliament and of the

413 Council and Regulation (EC) No 726/2004 of the Parliament and of the Council.

414 Official Journal of the European Union, L152: 11-22.

415

416 EMEA-Committee for Veterinary Medicinal Products. 1996. Summary report on

417 Doxycycline hyclate EMEA/MRL/101/96-Final.

418

419 EFSA. 2007. Cross contamination of the non-target feedingstuffs by narasin authorised 420 for use as a feed additive. Scientific opinion of the panel on contaminants in the food 421 chain. The EFSA Journal 2007, 552, 1-35.

422

423 EFSA. 2007. Cross contamination of the non-target feedingstuffs by lasalocid 424 authorised for use as a feed additive. Scientific opinion of the panel on contaminants in 425 the food chain. The EFSA Journal 2007, 553, 1-46.

426

427 EFSA. 2008. Cross contamination of the non-target feedingstuffs by salinomycin 428 authorised for use as a feed additive. Scientific opinion of the panel on contaminants in 429 the food chain. The EFSA Journal 2008, 591, 1-38.

430

431 EFSA. 2008. Cross contamination of the non-target feedingstuffs by monensin

432 authorised for use as a feed additive. Scientific opinion of the panel on contaminants in 433 the food chain. The EFSA Journal 2008, 592, 1-40.

434 
435 EFSA. 2008. Cross contamination of the non-target feedingstuffs by semduramicin 436 authorised for use as a feed additive. Scientific opinion of the panel on contaminants in 437 the food chain. The EFSA Journal 2008, 593, 1-27.

438

439 EFSA. 2008. Cross contamination of the non-target feedingstuffs by maduramicin 440 authorised for use as a feed additive. Scientific opinion of the panel on contaminants in 441 the food chain. The EFSA Journal 2008, 594, 1-30.

442

EFSA. 2008. Cross contamination of the non-target feedingstuffs by robenidine

444 authorised for use as a feed additive. Scientific opinion of the panel on contaminants in 445 the food chain. The EFSA Journal 2008, 655, 1-29.

446

447 EFSA. 2008. Cross contamination of the non-target feedingstuffs by halofuginone 448 authorised for use as a feed additive. Scientific opinion of the panel on contaminants in 449 the food chain. The EFSA Journal 2008, 657, 1-31.

450

451

EFSA. 2008. Cross contamination of the non-target feedingstuffs by nicarbazin 452 authorised for use as a feed additive. Scientific opinion of the panel on contaminants in 453 the food chain. The EFSA Journal 2008, 690, 1-34.

EFSA. 2008. Cross contamination of the non-target feedingstuffs by diclazuril 456 authorised for use as a feed additive. Scientific opinion of the panel on contaminants in 457 the food chain. The EFSA Journal 2008, 716, 1-31. 
459 Epstein, R.L.; Ashworth, R.B. 1989. Tissue sulfonamide concentration and correlation 460 in turkeys. Am. J. Vet. Res. 50(6): 926-928.

461

462 FEFAC. 2009. European Feed Manufacturers Guide: A community guide to good

463 practice for the EU industrial compound feed and premixtures manufacturing sector for 464 food producing animals. Available at:

465 http://ec.europa.eu/food/food/foodlaw/guidance/guidance_rev_7_en.pdf

466

467 Heberer, T.; Lahrssen-Wiederholt, M.; Schafft, H.; Abraham, K.; Pzyrembel, H.;

468 Henning, K.J.; Schauzu, M.; Braeunig, J.; Goetz, M.; Niemann, L.; Gundert-Remy, U.;

469 Bol, G.F.; Lampen, A.; Wittkowski, R.; Hensel, A. 2007. Zero tolerance in food and

470 animal feed - Are there any scientific alternatives? A European point of view on an

471 international controversy. Toxicol. Lett.175: 118-135

472

473 Kan, C.A.; Petz, M. 2000. Residues of veterinary drugs in eggs and their distribution 474 between yolk and white. J. Agric. Food Chem. 48: 6397-6403.

475

476 Kan, C.A.; Meijer, G.A.L. 2007. The risk of contamination of food with toxic 477 substances present in animal feed. An. Feed Sc. Technol. 133: 84-108.

478

479 Kennedy, D.G.; Cannavan, A.; McCracken, R.J. 2000. Regulatory problems caused bu 480 contamination, a frequently overlooked cause of veterinary drug residues. J. 481 Chromatogr. A. 882: 37-52. 
483 McEvoy, J.D.G. 2002. Contamination of animal feedingdstuffs as a cause of residues in

484 food: a review of regulatory aspects, incidence and control. Anal. Chim. Acta, 473: 3485 26.

486

487

Mortier, L.; Daeseleire, E.; Van Peteghem, C. 2005. Determination of the coccidiostat 488 diclazuril in poultry feed and meat by liquid chromatography-tandem mass 489 spectrometry. Anal. Chim. Acta, 529: 229-234.

490

Mortier, L.; Daeseleire, E.; Van Peteghem, C. 2005. Determination of the ionophoric 492 coccidiostats narasin, monensin, lasalocid and salinomycin in eggs by liquid 493 chromatography/tandem mass spectrometry. Rapid Commun Mass Spectrom., 19: 533494 539.

495

Mulder, P.P.J.; Balzer-Rutgers, P.; te Brinke, E.M.; Bolck, Y.J.C.; Berendsen, B.J.A.;

497 Gerçek, H.; Schat, B.; van Rhijn, J.A. 2005. Deposition and depletion of the 498 coccidiostats toltrazuril and halofuginone in eggs. Anal. Chim. Acta, 529: 331-337

499

500 Rosén, J. 2001. Efficient and sensitive screening and confirmation of residues of

501 selected polyether ionophore antibiotics in liver and eggs by liquid chromatography-

502 electrospray tandem mass spectrometry. Analyst, 126: 1990-1995

503

504 Roudaut, B.; Garnier, M. 2002. Sulphonamide residues in eggs following drug 505 administration via drinking water. Food Addit. Contam. 19: 373-378. 
507 Takahashi, Y. 1986. Mechanism of nonlinear pharmacokinetics of sulfadimethoxine in

508 cocks. Jpn. J. Vet. Sci., 48: 105-109.

509

510 Tansakul, N.; Niedorf, F.; Kietzmann, M. 2007. A sulfadimidine model to evaluate

511 pharmacokinetics and residues at various concentrations in laying hens. Food Addit.

512 Contam. 24: 598-604.

513

514 Yakkundi, S.; Cannavan, A.; Young, P.B.; Elliott, C.T.; Kennedy D.G. 2002.

515 Halofuginone contamination in feeds as a cause of residues in eggs. Anal. Chimica 516 Acta, 473: 177-182.

517 
$518 \quad$ Figure captions

519

520 Figure 1. HPLC-DAD chromatograms. From top to bottom: doxycycline reference

521 standard solution corresponding to $50 \mu \mathrm{g} \mathrm{kg}^{-1}$, a negative muscle sample, a muscle

522 sample spiked at $50 \mu \mathrm{g} \mathrm{kg}^{-1}$ and a muscle sample from a group 2 animal (id. nb.142)

523

524 Figure 2. HPLC-ESI-MS/MS chromatograms. From top to bottom: sulfadimethoxine 525 reference standard solution corresponding to $20 \mu \mathrm{g} \mathrm{kg}^{-1}$, a negative muscle sample, a 526 muscle sample spiked at $10 \mu \mathrm{g} \mathrm{kg}^{-1}$ and a muscle sample from a group 3 animal (id. 527 nb.143) (I.S. sulfadimethoxine-d6 not shown) 


\section{Tables and captions}

Table 1. HPLC-DAD conditions for doxycycline and metacycline.

\begin{tabular}{|c|c|c|c|}
\hline $\begin{array}{l}\text { Time } \\
\text { [minutes] }\end{array}$ & $\begin{array}{c}\% \\
\text { Acetonitrile }\end{array}$ & $\begin{array}{c}\% \text { Oxalic } \\
\text { acid } \\
0.01 \mathrm{M} \\
\end{array}$ & $\%$ Methanol \\
\hline $0.0-1.0$ & 9 & 70 & 21 \\
\hline $1.0-6.0$ & 22 & 70 & 8 \\
\hline $6.0-12.0$ & 22 & 70 & 8 \\
\hline $12.0-13.0$ & 9 & 70 & 21 \\
\hline \multicolumn{2}{|l|}{ Flow rate } & \multicolumn{2}{|l|}{$0.6 \mathrm{ml} \mathrm{min}^{-1}$} \\
\hline \multicolumn{2}{|c|}{ HPLC Column } & \multicolumn{2}{|c|}{$\begin{array}{l}\mathrm{C} 18, \quad 2.7 \mu \mathrm{m}, \quad(150 \quad \mathrm{x} \\
\text { 4.6)mm, Ascentis Express } \\
\text { (Supelco) }\end{array}$} \\
\hline \multicolumn{2}{|c|}{ Injection Volume } & \multicolumn{2}{|c|}{$20 \mu 1$} \\
\hline \multicolumn{2}{|c|}{ Autosampler temperature: } & \multicolumn{2}{|c|}{$5^{\circ} \mathrm{C}$} \\
\hline \multicolumn{2}{|c|}{ Column temperature: } & \multicolumn{2}{|c|}{$30^{\circ} \mathrm{C}$} \\
\hline \multicolumn{4}{|c|}{ Detection system: UV-DAD. Operative conditions } \\
\hline \multicolumn{2}{|c|}{ Monitoring wavelenght } & \multicolumn{2}{|c|}{$355 \mathrm{~nm}$} \\
\hline \multicolumn{2}{|c|}{ UV spectrum range } & \multicolumn{2}{|c|}{$210-450 \mathrm{~nm}$} \\
\hline
\end{tabular}


Table 2. HPLC-MSMS conditions for Sulfadimethoxine and Sulfadimethoxine-d6

\begin{tabular}{|c|c|c|}
\hline Time [minutes] & $\begin{array}{l}\% \text { Formic acid } \\
0.1 \%\end{array}$ & $\%$ Acetonitrile \\
\hline $0.0-1.0$ & 95 & 5 \\
\hline $1.0-15.0$ & 70 & 30 \\
\hline $15.0-16.5$ & 70 & 30 \\
\hline $16.5-17.0$ & 10 & 90 \\
\hline $17.0-19.0$ & 9 & 70 \\
\hline $19.0-20.0$ & 95 & 5 \\
\hline Flow rate & \multicolumn{2}{|c|}{$0.25 \mathrm{ml} \mathrm{min}^{-1}$} \\
\hline HPLC column & \multicolumn{2}{|c|}{$\begin{array}{l}\text { Phenyl, } 3.5 \mu \mathrm{m}, \quad\left(\begin{array}{lll}100 & \mathrm{x} & 2.1) \mathrm{mm} \text {, } \\
\text { XTerra (Waters) }\end{array}\right. \\
\end{array}$} \\
\hline Injection volume & \multicolumn{2}{|c|}{$10 \mu \mathrm{l}$} \\
\hline $\begin{array}{l}\text { Autosampler } \\
\text { temperature: }\end{array}$ & \multicolumn{2}{|c|}{$5^{\circ} \mathrm{C}$} \\
\hline Column temperature: & \multicolumn{2}{|c|}{$30^{\circ} \mathrm{C}$} \\
\hline \multicolumn{3}{|c|}{ Detection system: MS/MS analyzer. Operative conditions } \\
\hline $\begin{array}{l}\text { Sulfadimethoxine } \\
\text { MSMS transitions } \\
\text { (Collision Energy) } \\
\end{array}$ & \multicolumn{2}{|c|}{$\begin{array}{cc}\mathrm{m} / \mathrm{z}: 311>156 & \mathrm{~m} / \mathrm{z}: 311>108 \\
(20 \mathrm{eV}) & (28 \mathrm{eV})\end{array}$} \\
\hline $\begin{array}{l}\text { Sulfadimethoxine-d6 } \\
\text { MSMS transition } \\
\text { (Collision Energy) }\end{array}$ & \multicolumn{2}{|c|}{$\mathrm{m} / \mathrm{z}: 317>156 \quad(20 \mathrm{eV})$} \\
\hline Ionization mode & \multicolumn{2}{|c|}{$\mathrm{ESI}+$} \\
\hline Capillary voltage & \multicolumn{2}{|c|}{$3.20 \mathrm{kV}$} \\
\hline Cone voltage & \multicolumn{2}{|c|}{$40 \mathrm{~V}$} \\
\hline Source temperature & \multicolumn{2}{|c|}{$125^{\circ} \mathrm{C}$} \\
\hline $\begin{array}{l}\text { Desolvation } \\
\text { temperature }\end{array}$ & \multicolumn{2}{|c|}{$350^{\circ} \mathrm{C}$} \\
\hline $\begin{array}{l}\text { Desolvation gas } \\
\text { (nitrogen) flow }\end{array}$ & \multicolumn{2}{|c|}{$9001 \mathrm{hr}^{-1}$} \\
\hline Cone gas flow & \multicolumn{2}{|c|}{$501 \mathrm{hr}^{-1}$} \\
\hline
\end{tabular}


Table 3. Recovery, precision, decision limit $(\mathrm{CC} \alpha)$ and detection capability $(\mathrm{CC} \beta)$, limit of detection (LoD) and limit of quantification (LoD) of the analytical methods for doxycycline and sulfadimethoxine determination in chicken muscle

\begin{tabular}{|c|c|c|c|c|c|c|c|c|}
\hline & $\begin{array}{c}\text { Fortification } \\
\text { levels } \\
{\left[\mu \mathrm{g} \mathrm{kg}^{-1}\right]}\end{array}$ & $\begin{array}{c}\text { Mean found } \\
{\left[\mu \mathrm{gg}^{-1}\right]}\end{array}$ & $\begin{array}{c}\text { Recovery } \\
(\%)\end{array}$ & $\begin{array}{l}\text { Precision } \\
\text { R.S.D. (\%) }\end{array}$ & $\begin{array}{c}\text { LoD } \\
{\left[\mu \mathrm{g} \mathrm{kg}^{-1}\right]}\end{array}$ & $\begin{array}{c}\mathrm{LoQ} \\
{\left[\mu \mathrm{g} \mathrm{kg}^{-1}\right]}\end{array}$ & $\begin{array}{c}\mathrm{CC} \alpha \\
{\left[\mu \mathrm{g} \mathrm{kg}^{-1}\right]}\end{array}$ & $\begin{array}{c}\mathrm{CC} B \\
{\left[\mu \mathrm{g} \mathrm{kg}^{-1}\right]}\end{array}$ \\
\hline \multirow{4}{*}{ Doxycycline } & 25 & 21.5 & 85.9 & 11.0 & \multirow{4}{*}{14.6} & \multirow{4}{*}{24.8} & \multirow{4}{*}{109} & \multirow{4}{*}{118} \\
\hline & 50 & 41.0 & 82.1 & 8.9 & & & & \\
\hline & 100 & 80.7 & 80.7 & 6.7 & & & & \\
\hline & 150 & 119.7 & 79.8 & 7.0 & & & & \\
\hline \multirow{4}{*}{ Sulfadimethoxine } & 20 & 22.2 & 110.8 & 7.2 & \multirow{4}{*}{8.6} & \multirow{4}{*}{14.6} & \multirow{4}{*}{106} & \multirow{4}{*}{112} \\
\hline & 50 & 47.9 & 95.8 & 3.1 & & & & \\
\hline & 100 & 93.9 & 93.9 & 4.0 & & & & \\
\hline & 150 & 141.5 & 94.3 & 4.0 & & & & \\
\hline
\end{tabular}

Note: ${ }^{a}$ Mean value of 6 repetitions for each fortification level on each day, three series on three different days 
Table 4. Measured concentrations of doxycycline and sulfadimethoxine in muscle, liver and kidney after 10 days administration of contaminated feed.

\begin{tabular}{|c|c|c|c|c|}
\hline Group & $\begin{array}{l}\text { Animal } \\
\text { number }\end{array}$ & $\begin{array}{c}\text { Muscle } \\
{\left[\mu \mathrm{g} \mathrm{kg}^{-1}\right]}\end{array}$ & $\begin{array}{c}\text { Liver } \\
{\left[\mu \mathrm{g} \mathrm{kg}^{-1}\right]}\end{array}$ & $\begin{array}{c}\text { Kidney } \\
{\left[{\left.\mu \mathrm{g} \mathrm{kg}^{-1}\right]}\right.}\end{array}$ \\
\hline \multirow{4}{*}{ CONTROL } & 131 & N.D. ${ }^{\mathrm{a}}$ & N.D. & N.D. \\
\hline & 132 & N.D. & N.D. & N.D. \\
\hline & 133 & N.D. & N.D. & N.D. \\
\hline & 134 & N.D. & N.D. & N.D. \\
\hline \multirow{8}{*}{ Doxycycline } & 135 & 34.2 & 52.9 & 107.4 \\
\hline & 136 & 20.2 & 38.1 & 77.1 \\
\hline & 137 & 20.2 & 43.3 & 77.7 \\
\hline & 138 & 22.5 & 40.1 & 89.2 \\
\hline & 139 & 22.6 & 35.4 & 91.7 \\
\hline & 140 & 49.7 & 95.5 & 185.2 \\
\hline & 141 & 29.3 & 64.6 & 123.3 \\
\hline & 142 & 47.5 & 78.6 & 165.7 \\
\hline Average & & 30.8 & 56.1 & 114.7 \\
\hline $\begin{array}{l}\text { Standard } \\
\text { dev. }\end{array}$ & & 12.0 & 21.8 & 40.8 \\
\hline MRL & & 100 & 300 & 600 \\
\hline \multirow{8}{*}{$\begin{array}{l}\text { Sulfa- } \\
\text { dimethoxine }\end{array}$} & 143 & 6.9 & 18.9 & 80.1 \\
\hline & 144 & 2.2 & 5.8 & 34.7 \\
\hline & 145 & 6.2 & 15.5 & 87.4 \\
\hline & 146 & 6.8 & 17.6 & 82.7 \\
\hline & 147 & 4.4 & 9.5 & 40.2 \\
\hline & 148 & 3.8 & 12.7 & 50.6 \\
\hline & 149 & 5.9 & 16.3 & 48.6 \\
\hline & 150 & 2.1 & 5.7 & 27.0 \\
\hline Average & & 4.8 & 12.8 & 56.4 \\
\hline $\begin{array}{l}\text { Standard } \\
\text { dev. }\end{array}$ & & 2 & 5.2 & 23.6 \\
\hline MRL & & 100 & 100 & 100 \\
\hline
\end{tabular}

Note: ${ }^{\mathrm{a}}$ N.D. $=$ not detected 

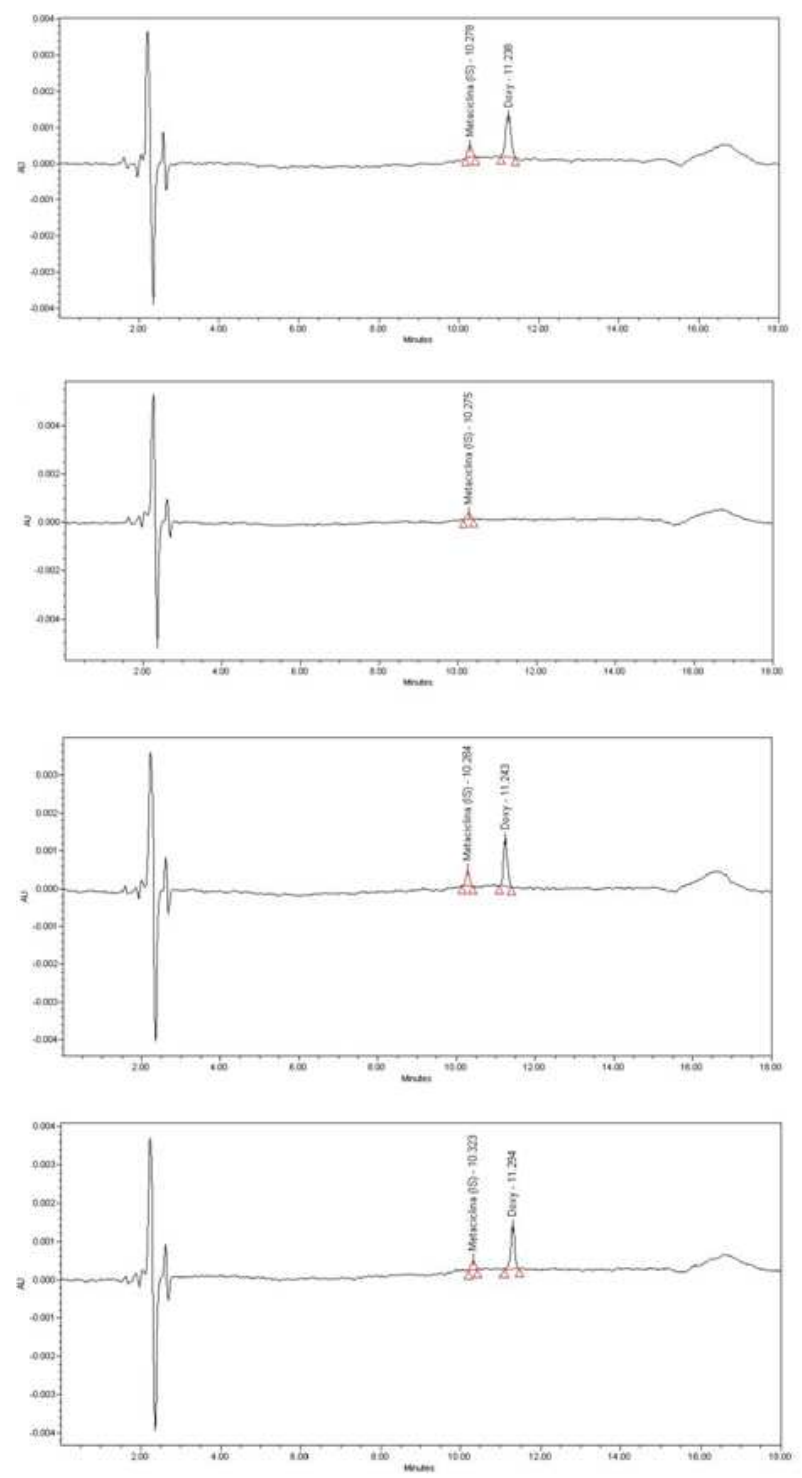

Figure 1. HPLC-DAD chromatograms. From top to bottom: doxycycline reference standard solution corresponding to $50 \mu \mathrm{g} \mathrm{kg}-1$, a negative muscle sample, a muscle sample spiked at $50 \mu \mathrm{g} \mathrm{kg}-1$ and a muscle sample from a group 2 animal (id. nb.142) $138 \times 244 \mathrm{~mm}(96 \times 96 \mathrm{DPI})$ 
Figure 2. HPLC-ESI-MS/MS chromatograms. From top to bottom: sulfadimethoxine reference standard solution corresponding to $20 \mu \mathrm{g} \mathrm{kg}-1$, a negative muscle sample, a muscle sample spiked at $10 \mu \mathrm{g} \mathrm{kg}-1$ and a muscle sample from a group 3 animal (id. nb.143) (I.S. sulfadimethoxine-d6 not shown)

$282 \times 209 \mathrm{~mm}(96 \times 96 \mathrm{DPI})$ 